\title{
Memenuhi Hak Anak Berkebutuhan Khusus Anak Usia Dini Melalui Pendidikan Inklusif
}

\author{
Sri Muji Rahayu \\ pamardiputa@yahoo.co.id \\ SLB Pamardi Putra Bantul
}

\begin{abstract}
Abstrak
Hak anak adalah bagian dari hak asasi manusia yang wajib dijamin, dilindungi, dan dipenuhi oleh orang tua, keluarga, masyarakat, pemerintah, dan negara. Hak anak yang wajib dipenuhi diantaranya adalah hak untuk memperoleh pendidikan dan pengajaran. Anak berkebutuhan khusus usia dini juga berhak mendapatkan layanan pendidikan. Anak berkebutuhan khusus usia dini yang ada di masyarakat belum semuanya mendapatkan layanan di pendidikan anak usia dini. Hal ini disebabkan karena keberadaan pendidikan anak usia dini belum mampu memberikan pelayanan sesuai dengankebutuhannya. Untuk memberikan pelayanan anak berkebutuhan khusus usia dini, maka pendidikan anak usia dini yang telah ada seharusnya dapat menerima dan melayani anak berkebutuhan khusus. Pelayanan pendidikan anak usia dini yang memberikan pelayanan bersama-sama antaraanak yang tidak mengalami hambatan dan anak berkebutuhan khusus disebut pendidikan anak usia dini inklusif. Pendidikan inklusif adalah sistem pendidikan yang menyertakan semua anak secara bersama-sama dalam suatu iklim proses pembelajaran dengan penyelenggaraan pendidikan yang memberikan kesempatan kepada semua anak secara bersama-sama dalam suatu iklim proses pembelajaran dengan layanan pendidikan yang layak dan sesuai kebutuhan individu siswa tanpa membedakan anak dari latar belakang suku, ras, status sosial, kemampuan ekonomi, status politik, bahasa, geografis, jeniskelamin, agama/kepercayaan, dan perbedaan kondisi fisik atau mental.
\end{abstract}

Kata kunci: hak anak, anak berkebutuhan khusus usia dini, pendidikan inklusif

\begin{abstract}
The right of children is a part of human right that should be fulfilled, protected and assured by parents, families, societies, civils and nations. One of children rights that should be fullfilled is the right to get education.Most special need pre-school age students haven't got the education in pre-school yet. This happened because the existence of pre-school education hasn't been able to give some services that is suitable with their need. To give services to special need pre-school age students, the pre-school education that has been exist should be able to give services to special need students. The service of pre-school age education that gives service not only to normal students but also to special need students colled inclusive pre-school age education. Inclusive education is an education existing all students in a kind of learning process by holding an education giving chance to all students to study together in a certain learning process that is suitable with the need of every students without thingking about the ethnic, race, social statue, economic condition, language, place, sex, religion and differentiation of mental and physical condition.
\end{abstract}

Keywords: the right of children, pre-school age students, inclusive education. 


\section{Pendahuluan}

Pendidikan merupakan usaha sadar dan terencana untuk mewujudkan suasana belajar dan proses pembelajaran agar peserta didik secara aktif mengembangkan potensi dirinya untuk memiliki kekuatan spiritual keagamaan, pengendalian diri, kepribadian, kecerdasan, akhlak mulia, serta ketrampilan yang diperlukan dirinya, masyarakat, bangsa dan negara. Saat inihampir di setiap desa berdiri pendidikan anak usia dini (PAUD) yang dikelola oleh Departemen pendidikan dan Kebudayaan, Departemen Agama, yayasan maupun lembaga sosial lainnya. Dari tahun ke tahun perhatian pemerintah terhadap layanan PAUD semakin meningkat sehingga kesadaran masyarakat untuk mengelola PAUD juga semakin banyak. Hadirnya PAUD yang semakin berkembang ini akan memberikan pengaruh yang positif yaitu semakin banyak anak-anak usia dini yang dapat menikmati layanan PAUD sehingga anakanak usia 0-6 tahun pertumbuhan dan perkembangannDalam Undang-undang Nomor 20 Tahun 2003 tentang sistem pendidikan nasional pasal 1 ayat 4 menyatakan, "Pendidikan anak usia dini adalah suatu upaya pembinaan yang ditujukan kepada anak sejak lahir sampai dengan usia enam tahun yang dilakukan melalui pemberian rangsangan pendidikan untuk membantu pertumbuhan dan perkembangan jasmani dan rohani agar anak memiliki kesiapan dalam dalam memasuki pendidikan lebih lanjut.

Rumusan pasal itu mengandung makna bahwa semua anak usia $0-6$ tahun memiliki hak untuk mendapatkan layanan PAUD. Dalam pasal itu bermakna bahwa anak usia 0-6 tahun termasuk didalamnya anak berkebutuhan khusus. Anak berkebutuhan khusus juga memiliki hak yang sama dengan anak yang lainnya sehingga mereka berhak mendapatkan layanan sesuai dengan kebutuhannya. Undang-undang Nomor 23 Tahun 2003 tentang Perlindungan Anak menyatakan bahwa:
1. Setiap anak berhak memperoleh pendidikan dan pengajaran dalam rangka pengembangan pribadinya dan tingkat kecerdasannya sesuai dengan minat dan bakatnya.

2. Setiap anak berhak untuk dapat hidup, tumbuh, berkembang dan berpartisipasi secara wajar sesuai dengan harkat dan martabat kemanusiaan serta mendapat perlindungan dari kekerasan dan diskriminasi.

Berdasarkan undang-undang itu dapat disimpulkan bahwa semua anak berhak mendapatkan pendidikan termasuk di dalamnya anak berkebutuhan khusus usia dini.

\section{Anak Usia Dini}

Masa anak merupakan masa di mana segala kesempatan dapat berkembang dan dikatakan sebagai masa kritis dalam perkembangan. Ada lima hal penting bagi tumbuh kembang anak. Pertama, perkembangan penglihatan. Kemampuan penglihatan harus dirangsang pada empat tahun pertama. Kedua, perkembangan perasaan emosi. Sejak umur dua bulan sampai sekitar empat tahun mulai berkembang perasaan stress, kepuasan, perasaan girang dan sedih. Ketiga, perkembangan kemampuan bahasa. Perkembangan kemampuan bahasa dimulai sejak dalam kandungan, ditentukan oleh seberapa banyak anak diajak bicara dan mendengarkan. Keempat, perkembangan kemampuan gerak. Masa kritis perkembangan gerakan berlangsung sejak lahir sampai umur dua tahun. Perkembangan motorik kasar berlangsung hingga umur empat tahun. Kelima, perkembangan kemampuan musik. Masa kritis perkembangan kemampuan musik terjadi antara 3-10 tahun.

\section{Pendidikan Inklusif Untuk Anak UsiaDini}

Sampai saat anak berkebutuhan yang berusia 0-6 tahun belum semua mendapatkan layanan PAUD sesuai 
dengan kebutuhannya. Pemenuhan hak pendidikan untuk anak usiadini dapat dilakukan dengan melayani mereka melalui pendidikan inklusif. Pendidikan inklusif merupakan salah satu upaya agar anak-anak usia 0-6 tahun yang mengalami atau membutuhkan layanan khusus dapat berkembang dan tumbuh secara optimal sesuai dengan tugas-tugas perkembangannya.

Pendidikan inklusif saat ini menjadi isu yang sangat menarik di tengah-tengah dunia pendidikan di negara kita, karena pendidikan inklusif memberikan perhatian pada peserta didik yang memiliki kelainan atau kebutuhan khusus untuk mendapatkan layanan pendidikan khusus pada sekolah umum atau regular.Untuk memenuhi hak anak usia 0-6 tahun yang mengalami kelainan atau berkebutuhan khusus perlu adanya PAUD yang inklusif.

Pendidikan inklusif merupakan usaha pemerintah dalam bidang pendidikan agar semua warga negara dapat mendapatkan layanan pendidikan termasuk di dalamnya adalah anak berkebutuhan khusus. Anak berkebutuhan khusus usia dini belum semuanya merasakan pendidikan anak usia dini yang telah ada di masyarakat. Hal ini disebabkan belum semua penyelenggara PAUD dapat melayani anak berkebutuhan khusus usia dini. Pendidikan inklusif adalah suatu sistem pendidikan yang menyertakan semua anak secara bersama-sama dalam suatu iklim proses pembelajaran dengan penyelenggaraan pendidikan yang memberikan kesempatan kepada semua anak secara bersama-sama dalam suatu iklim proses pembelajaran dengan layanan pendidikan yang layak dan sesuai kebutuhan individu siswa tanpa membedakan anak dari latar belakang suku, ras, status sosial, kemampuan ekonomi, status politik, bahasa, geografis, jenis kelamin, agama/kepercayaan, dan perbedaan kondisi fisik atau mental (UNESCO 2004). Permendiknas no.70 tahun 2009 menyatakan bahwa semua anak usia sekolah yang mengalami kelainan berhak mendapatkan layanan pendidikan bersama-sama dengan peserta didik pada umumnya.

Anak berkebutuhan khusus harus mendapatkan perlakuan yang sama dalam memperoleh pendidikan yang layak dan bermutu. Anak berkebutuhan khusus usia dini berhak mendapatkan layanan pendidikan inklusi. Direktorat Pendidikan Luar Biasa (2004) memberikan arahan bahwa yang dimaksud dengan inklusif adalah keterbukaan untuk belajar bersama bagi semua peserta didik tanpa kecuali. Anak berkebutuhan khusus yang harus mendapatkan layanan pendidikan inklusif adalah:

1. Tunanetra

Tunanetra menurut Rini Hildayani (dalam Telford \& Sawrey) adalah anak yang tidak dapat menggunakan penglihatannya untuk tujuan belajar sehingga pendidikan mereka secara utama diberikan melalui indera pendengaran, peraba, dan kinestetik.

2. Tunarungu

Rini Hildayani (dalam Suran \& Rizzo) menyatakan bahwa tunarungu adalah anak yang mengalami gangguan pendengaran sehingga menghalangi keberhasilan mereka untuk memproses informasi bahasa melalui indera pendengaran dengan atau tanpa alat bantu pendengaran.

3. Tunawicara

Tati Hermawati menjelaskan bahwa tunawicara adalah anak yang mengalami hambatan dalam perkembangan bicaranya secara normal atau kemampuan bicaranya tidak terbentuk.

4. Tunagrahita

American Assosiation on Mental
Retardation yang dimaksud
tunagrahita adalah anak dengan
keterbelakangan mental menunjukkan
keterlambatan perkembangan di
hamper seluruh aspek fungsi
akademik dan fungsi sosialnya dan
menunjukkan ciri-ciri: memiliki taraf


kecerdasan yang secara signifikan berada di bawah rata-rata kecerdasan umum anak sebayanya. Keadaan ini diindikasikan dengan nilai IQ yang berada di bawah 70 dan kemampuan belajarnya lebih lambat dan memiliki prestasi belajar jauh di bawah rata-rata kelasnya dan merata hampir di seluruh mata pelajaran,

5. Tunadaksa

Astati (2007) menyatakan bahwa tunadaksa adalah anak yang mengalami bentuk kelainan atau kecacatan pada system otot, tulang, dan persendian yang dapat mengakibatkan gangguan koordinasi, komunikasi, adaptasi, mobilisasi, dan gangguan perkembangan keutuhan pribadi.

6. Tunalaras

Astati (2007) menyatakan tunalaras adalah anak yang mengalami penyimpangan perilaku yang terus menerus menurut norma yang berlaku, sehingga menimbulkan ketidakmampuan belajar dan penyesuaian diri.

7. Berkesulitan belajar

Tati Hermawati menyatakan bahwa anak anak berkesulitan belajar adalah anak yang mengalami kesulitan dalam tugas-tugas akademiknya, yang disebabkan oleh adanya disfungsi minimal otak atau dalam psikologis dasar sehingga prestasi belajarnya tidak sesuai dengan potensi yang sebenarnya, dan untuk mengembangkan potensinya secara optimal, mereka memerlukan pelayanan pendidikan secara khusus.

8. Lamban belajar

Lamban belajar adalah anak yang kurang mampu menguasai pengetahuan dalam batas waktu yang telah ditentukan karena ada faktor tertentu yang mempengaruhinya (cucurdini).

9. Autis

Autis menurut Eko Handayani adalah anak yang mengalami gangguan perkembangan yang muncul di awal kehidupan seorang anak (biasa nampak pada masa infancy atau toodlerhood) yang ditandai oleh ketidakmampuan anak untuk berhubungan dengan orang lain, adanya masalah dalam hal berkomunikasi dan muncul kebutuhan untuk melaksanakan aktivitas yang sama dan berulang.

10. Memiliki gangguan motorik

Memiliki gangguan motorik adalah anak yang sering memperlihatkan adanya gerakan melimpah (overflow movement), kurang koordinasi dalam aktivitas motorik, kesulitan koodinasi motorik halus dan sebagainya (slideshare.net)

11. Menjadi korban penyalahgunaan narkoba, obat terlarang dan zat aditif lainnya.

12. Memiliki kelainan lainnya.

13. Tunaganda

Tunaganda adalah anak yang mengalami kelainan lebih dari satu jenis kelainan.

\section{Tujuan Pendidikan Inklusif}

Tujuan pendidikan inklusi adalah: memberikan kesempatan yang seluasluasnya kepada semua peserta didik yang memiliki kelaianan fisik, emosional, mental dan sosial atau memiliki potensi kecerdasan dan/atau bakat istimewa untuk memperoleh pendidikan yang bermutu sesuai dengan kebutuhan dan kemampuannya serta mewujudkan penyelenggaraan pendidikan yang menghargai keanekaragaman dan tidak diskriminatif bagi semua peserta didik.

Sasaran pendidikan inklusif secara umum adalah semua peserta didik yang ada di sekolah regular, yaitu anak berkebutuhan khusus maupun anak normal. Mereka secara keseluruhan harus memahami dan menerima keanekaragaman dan perbedaan individual yaitu: 
1. Anak berkebutuhan khusus yang sudah bersekolah di sekolah dasar/Madrasah Ibtidaiyah

2. Anak berkebutuhan khusus yang akan masuk ke sekolah dasar/Madrasah Ibtidaiyah.

3. Anak berkebutuhan khusus yang belum/tidak bersekolah.

4. Anak berkebutuhan khusus yang akan mengikuti program pendidikan non formal atau informal.

Melihat sasaran pendidikan inklusif tersebut maka sudah seharusnya anak berkebutuhan khusus mendapatkan haknya yaitu memperoleh pendidikan di sekolah inklusif. Terbatasnya PAUD inklusif menyebabkan anak berkebutuhan khusus usia dini mengalami kesulitan mengakses pendidikan yang seharusnya menjadi haknya.

\section{Prinsip-prinsip Penyelenggaraan Pendidikan Inklusif \\ Prinsip-prinsip penyelenggaraan \\ pendidikan inklusif adalah:}

1. Humanisme artinya bahwa sistem pendidikan inklusif mengutamakan nilai kemanusiaan, menempatkan peserta didik sebagai manusia yang merupakan makluk kodrati, bagian dari alam dan makluk sosial dengan berbagai potensinya masing-masing.

2. Uniberalisme, artinya bahwa sistem pendidikan inklusi menempatkan setiap peserta didik sebagai makhluk yang unik, sehingga setiap peserta didik diakui keberadaannya dengan segala kondisi dan potensinya, dan hal ini merupakan kesempurnaan mereka masing-masing, sehingga mereka harus mendapatkan layanan pendidikan sesuai dengan kondisi dan potensinya. Mereka tidak layak dibandingkan dengan anak-anak normal. Oleh karena itu sistem pendidikan sebaiknya tidak menggunakan pendekatan kompetitif, tetapi lebih mengedepankan pendekatan kooperatif.
3. Pluralisme dan non diskriminatif, artinya bahwa setiap individu adalah berbeda antara yang satu dengan yang lain. Dalam hal ini perbedaan setiap peserta didik merupakan keniscayaan, demikian pula perbedaan perbedaan kondisi, potensi, dan latar belakang kehidupannya, sehingga perbedaan kebutuhan di antara mereka merupakan hal yang esensial. Sistem pendidikan inklusif memandang perbedaan anata individu merupakan kekayaan. Oleh karena itu sistem pendidikan inklusif memandang perbedaan antar individu merupakan kekayaan. Pendidikan inklusif menyelenggarakan proses pembelajaran bersama tanpa mendiskriminasikan individu atas dasar suku/etnis/ras, agama/kepercayaan, latar belakang sosial, ekonomi, politik, jenis kelamin, kemampuan fisik dan atau mental. Jadi mereka tidak memerlukan layanan yang setara dan sesuai dengan kondisi dan potensinya.

4. Demokratis, artinya sistem pendidikan inklusif menempatkan peserta didik sebagai partisipan pendidikan yaitu bahwa peserta didik menjadi pelaku aktif dan ikut dalam proses 0 pengambilan keputusan tentang hal yang akan mereka lakukan. Proses pembelajaran juga merupakan implementasi dari partisipasi dan keputusan bersama antar guru, administrator sekolah, siswa, orangtua, serta masyarakat lingkungan sekitar.

5. Menghormati hak asasi manusia, artinya sistem pendidikan inklusif memberikan kesempatan kepada semua anak bangsa tanpa membedakan dan bahkan memfasilitasi setiap individu dengan memperhatikan perbedaan kondisi dan potensinya masing-masing dalam suatu proses pembelajaran bersama dan berkembang sesuai dengan kondisi dan potensinya adalah hak 
setiap individu yang dijunjung tinggi dalam pelaksanaan sistem pendidikan inklusi. Hal ini selaras dengan hakekat asasi manusia yaitu hak setiap warga negara yang wajib dipenuhi dan dilindungi oleh pemerintah. Untuk menyelenggarakan sistem pendidikan inklusif, hal yang harus dilakukan adalah melaksanakan proses pengembangan komponen sistem pengelolaan pendidikan di sekolah penyelenggara pendidikan inklusif.

Pengelolaan komponen tersebut selayaknya menggunakan prinsip manajemen berbasis sekolah. Manajemen berbasis sekolah adalah model manajemen yang memberikan otonomi lebih besar kepada sekolah dan mendorong pengambilan keputusan partisipasi yang melibatkan secara langsung semua warga sekolah yaitu guru, siswa, kepala sekolah, karyawan, orang tua siswa, dan masyarakat untuk meningkatkan mutu sekolah berdasarkan kebijakan pendidikan nasional.

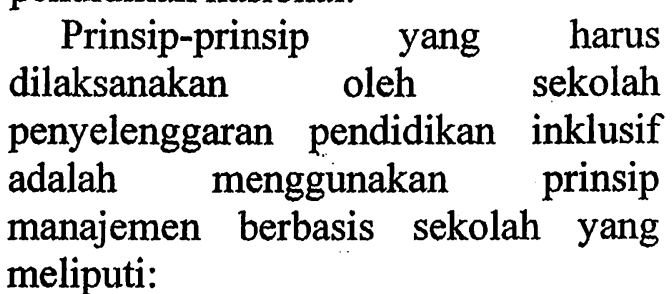

a. Perencanaan dan evaluasi program sekolah.

Sekolah diberi kewenangan untuk melakukan perencanaan sesuai dengan kebutuhannya untuk meningkatkan mutu sekolah. Sekolah penyelenggara pendidikan inklusif harus mewujudkan prinsip inklusifitas sejakdari perencanaan, proses penyelenggaraan, pemantauan atau pengawasan hingga penyusunan rencana tindak lanjut penyelenggara program sekolah.

b. Pengelolaan kurikulum

Kurikulum mencakup kurikulum nasional dan kurikulum muatan lokal. Kurikulum nsional merupakan standar nasional yang dikembangkan oleh
Departemen Pendidikan Nasional, sedangkan kurikulum muatan lokal merupakan kurikulum yang disesuaikan dengan keadaan dan kebutuhan lingkungan, yang disusun oleh Dinas pendidikan propinsidan/atau kota.

Kurikulum yang digunakan di kelas inklusif adalah kurikulum anak normal (regular) yang disesuaikan (dimodifikasi dengan kemampuan awal dan karakterisrtik siswa. Modifikasi dapat dilakukan dengan cara:

1) Modifikasi alokasi waktu.

2) Modifikasi isi/materi

3) Modifikasi proses belajar mengajar.

4) Modifikasi sarana prasarana

5) Modifikasi lingkungan belajar.

6) Modifikasi pengelolaan kelas.

c. Pengelolaan proses belajar mengajar.

Proses belajar mengajar merupakan kegiatan utama sekolah. Sekolah diberi kebebasan memilih strategi, metode, dan teknik pembelajaran yang paling efektif, sesuai dengan karakteristik siswa, sehingga lebih memberdayakan siswa. Pengelola sekolah penyelenggara pendidikan inklusif memiliki kewenangan mengembangkan proses pembelajaran bersama antar semua anak, tanpa kecuali termasuk didalamnya anak berkebutuhan khusus dengan tetap memperlihatkan pendekatan layanan yang sesuai dengan kondidi, potensi, serta kebutuhan individu siswa.

d. Pengelolaan ketenagaan

Tenaga kependidikan di sekolah meliputi tenaga pendidik, pengelola satuan pendidikan, pustakawan, dan laboran.Guru yang terlibat dalam sekolah penyelenggara inklusif adalah guru kelas, guru mata pelajaran, dan guru pembimbing khusus. Kekhasan program tenaga kependidikan pada sekolah penyelenggara pendidikan inklusif adalah pengaturan pembagian tugas dan pola kerja antar tenaga 
kependidikan khususnya antara guru regular dengan guru pembimbing khusus dalam memberikan layanan pendidikan khusus bagi peserta didik yang membutuhkan pendidikan khusus. Tenaga yang ada di sekolah penyelenggara pendidikan inklusif dituntut memiliki kompetensi yang meliputi kemampuan memodifikasi kurikulu, materi.Strategi, metode, alat dan media, serta model monitoring dan evaluasi pembelajaran sesuai dengan yang diperlukan oleh masingmasing individu siswa, terutama oleh siswa yang berkebutuhan khusus.

e. Pengelolaan sarana dan prasarana

Sarana dan prasarana yang dibutuhkan oleh anak berkebutuhan khusus adalah seperti yang digunakan oleh anak-anak normal, namun perlu adanya penyesuaian.Dalam pengadaan sarana dan prasarana sekolah penyelenggara pendidikan inklusif harus memiliki perpektif inklusif, sehingga sarana dan prasarana yang ada dapat mudah digunakan atau dicapai oleh semua warga sekolah termasuk untuk mereka yang berkebutuhan khusus.

f. Pengelolaan keuangan

Komponen keuangan sekolah merupakan komponen produksi yang menentukan terlaksananya kegiatan belajar mengajar bersama komponenkomponen yang lain. Dalam rangka penyelenggaraan pendidikan inklusif, perlu dialokasikan dana khusus, yang dapat digunakan untuk:

1) Kegiatan identifikasi input siswa.

2) Modifikasi kurikulum.

3) Insentif bagi tenaga kependidikan yang terlibat.

4) Pengadaan sarana dan prasarana.

5) Pemberdayaan peranserta masyarakat.

6) Pelaksanaan kegiatan belajar mengajar. g. Pelayanan siswa

Penerimaan siswa baru pada sekolah inklusif hendaknya memberi kesempatan dan peluang kepada anak berkebutuhan khusus untuk dapat diterima dan mengikuti pendidikan di sekolah penyelenggaran pendidikan inklusif. Pelayanan siswa meliputi antara lain:

1) Penerimaan siswa baru, termasuk di dalamnya aspek identifikasi, assesmen dan penempatan siswa.

2) Program bimbingan dan penyuluhan.

3) Pengelompokkan belajar siswa.

4) Kehadiran siswa.

5) Mutasi siswa.

6) Papan statistik siswa yang menggambarkan secar holistik tentang basis data kesiswaan.

7) Buku induk siswa.

h. Hubungan sekolah dan masyarakat

Esensi hubungan sekolah adalah untuk meningkatkan keterlibatan, kepedulian, kepemilikan dan dukungan dari masyarakat terutama dukungan moral dan finansial. Untuk menarik simpati masyarakat agar mereka bersedia berpartisipasi memajukan sekolah, perlu dilakukan berbagai hal, antara lain dengan cara memberitahu masyarakat mengenai program-program sekolah, baik program yang telah dilaksanakan, yang sedang dilaksanakan maupun yang akan dilaksanakan sehingga masyarakat mendapat informasi yang jelas tentang sekolah yang bersangkutan. Berkenaan dengan pelaksanaan pendidikan inklusif, keterlibatan masyaraka sangat diperlukan khususnya dalam rangka mensosialisasikan sekolah inklusif.

Pemahaman masyarakat tentang anak yang membutuhkan pendidikan khusus sangat berpengaruh terhadap kelancaran proses belajar mengajar. Hal ini akan berdampak pada sikap penerimaan masyarakat terhadap anakanak yang membutuhkan pendidikan khusus, yang selanjutnya akan 
mempengaruhi pula sikap anak didik lainnya yang belajar bersama-sama dengan anak yang membutuhkan pendidikan khusus, sehingga iklim belajar serta tata pergaulan di sekolah akan kondusif. Pengelola sekolah penyelenggara pendidikan inklusif dituntut untuk mampu menyelenggarakan kegiatan sosialisasi dengan media yang sesuai dengan jangkauan mereka dan harus mampu menjalin kerjasama dengan pihak lain untuk memenuhi kebutuhan sumberdaya yang mereka lakukan.

i. Pengelolaan iklim sekolah.

Iklim sekolah yang kondusif merupakan prasyarat bagi terselenggaranya proses belajar mengajar yang efektif. Lingkungan sekolah yang aman dan tertib, optimism, dan harapan yang tinggi dari warga sekolah, kesehatan sekolah, kegiatan berpusat pada siswa adalah contoh iklim sekolah yang dapat menumbuhkan semangat belajar siswa.

Pengelola sekolah penyelenggara pendidikan inklusif dituntut untuk mampu mengembangkan iklim psiko soaial yang akrab antar warga sekolah, sehingga siswa berkebutuhan khusus tidak merasa asing, namun merasa akrab dengan warga sekolah yang lain.

j. Kegiatan evaluasi

Kegiatan evaluasi dilakukan sebagai upaya untuk memperoleh gambaran terhadap kemajuan dan perubahan yang telah dicapai sekaligusa sebagai bahan untuk perencanaan program selanjutnya.

\section{Penutup}

Pendidikan adalah hak setiap warga negara, tidak terkecuali anak berkebutuhan khusus usia dini. Keberadaan pendidikan anak usia dini inklusif menjadi jawaban untuk memenuhi hak anak berkebutuhan khusus usia dini. Pelaksanaan pendidikan inklusif akan berhasil apabila sekolah tersebut menerapkan manejemen berbasis sekolah.

Pendidikan anak usia dini untuk anak berkebutuhan khusus perlu disiapkan sehingga mereka mendapatkan hak yang sama dalam mendapatkan layanan pendidikan. Pendidikan usia dini yang telah ada seharusnya dapat mengakomodir keberadaan anak berkebutuhan khusus sehingga diskriminasi pendidikan dapat dihindari dan perlu diterbitkannya surat keputusan yang berkekuatan hukum agar semua pendidikan anak usia dini bersifat inklusif.

\section{Daftar Rujukan}

Astati. (2007). Pengantar Pendidikan Luar Biasa. Jakarta: Universitas Terbuka.

---. (2001), Manajemen Peningkatan Mutu Berbosis Sekolah. Jakarta: Direktorat Jenderal Pendidikan Dasar dan Menengah.

-.---,. Undang-undang Republik Indonesia Nomor 23 Tahun 2002 tentang Perlindungan Anak.

-.-.-. Undang-undang Republik Indonesia Nomor 20 Tahun 2000 tentang Sistem Pendidikan Nasional: Bandung: Citra Umbara.

-.-.-. (2004) Pedoman Penyelenggaraan Pendidikan Terpadu/inklusi. Jakarta: Direktorat Pendidkan Luar Biasa.

----, Permendiknas no.70 tahun 2009 tentang inklusi.http://peduliinklusi. Blogspot.com. diunduh tanggal 2 Februari 2014.

Jaja Miharja. (2014) Pendidikan Inklusif. Makalah pada Seminar Pendidikan Anak Luar Biasa. Yogyakarta: Universitas Islam Indonesia 
Praptono. (2014). Aktualisasi Kebijakan Pendidikan dalam Pemerataan Kesempatan dan Akses serta Peningkatan Mutu melalui Program Pendidikan Inklusif.. Makalah pada Seminar Pendidikan Anak Luar Biasa. Yogyakarta: Universitas Islam Indonesia.

Rini Hildayani. (2008). Penanganan Anak Berkelainan. Jakarta: Universitas Terbuka.
Tati Hermawati. (2007). Pengantar Pendidikan Luar Biasa. Jakarta: Universitas Terbuka.

UNESCO, (2000). Salamanca Stetment. French: Graphoprint.

Yufiarti. (2008). Profesionalitas Guru $P A U D$. Jakarta: Universitas Terbuka. 